\title{
Wyobrażenia zbiorowe - próba kategoryzacji pojęcia
}

Zagadnienie wyobrażeń zbiorowych nie budzi - jak na razie - większego zainteresowania polskich politologów, socjologów, historyków, czy nawet antropologów i etnologów. Przyjmuje się, iż pojęcie to wprowadził do nauki Émile Durkheim, którego piśmiennictwo uznać można za „systematyczne studia nad wyobrażeniami zbiorowymi” - jak to ujął Steven Lukes ${ }^{1}$. Francuski socjolog definiował je jako formy działania, myślenia, uczuć jednostek, będące wynikiem ich poznawczych, emocjonalnych i praktycznych relacji ze wspólnotą, jak i reguł i zasad, które owa wspólnota wyznacza ${ }^{2}$. W kolejnych pracach pisał, że wyobrażenia zbiorowe to stany świadomości zbiorowej, wyrażające „sposób myślenia grupy o sobie samej w jej stosunkach z dotyczącymi jej przedmiotami”3. Durkheim w swoich dociekaniach koncentrował się na społeczeństwie jako całości, podkreślał, że jest ono nie tylko sumą jednostek, ale stanowi zupełnie inną jakość, stąd $\mathrm{w}$ jego piśmiennictwie pojawiało się wiele przemyśleń na temat przestrzeni kolektywnych.

Zauważając przydatność refleksji nad wyobrażeniami, nowe podejście próbowali rozwijać badacze ze szkoły Annales, jak np. Jacques Le Goff. Ten wybitny mediewista, dokonując rehabilitacji średniowiecza, starał się pokazać specyfikę stanów świadomości, charakterystyczną dla tamtych czasów.

* Doktor, Uniwersytet Łódzki, Wydział Studiów Międzynarodowych i Politologicznych, Katedra Teorii Polityki i Myśli Politycznej.

1 S. Lukes, Durkheim. Życie i dzieło, Warszawa 2012, s. 20.

2 I. Tappenbeck, Phantasie und Gesellschaft: Zur soziologischen Relevanz der Einbildungskraft, Würzburg 1999, s. 60.

3 Cyt. za: S. Lukes, op. cit., s. 20. Por. też: A. Karnat-Napieracz, Tożsamość, czyli świadomość Redivivus, Kraków 2009, s. 67. 
W swojej słynnej pracy Historia i pamięć twierdził, że rozwija się nowa forma historiografii, jaką nazwał „historią historii”. Jego zdaniem, „historia historii” miałaby badać manipulacje zjawiskami historycznymi przez pamięć zbiorową ${ }^{4}$. Pisał: „Sądzę, że historia historii powinna zajmować się nie tylko dokonaniami zawodowych historyków, lecz także całym zbiorem zjawisk tworzących kulturę historyczną czy, jeszcze lepiej, mentalność historyczną danej epoki" . Annaliści wychodzili z założenia, że tworzona przez nich nowa postać historii integralnej jako nauki o mentalnościach cywilizacji musi otworzyć się na dorobek innych dyscyplin, przede wszystkim ekonomii, socjologii, antropologii, geografii, psychologii ${ }^{6}$.

Z etymologicznego punktu widzenia nietrudno zauważyć, że termin „wyobrażenie”, podobnie jak „wyobraźnia”, pochodzi od obrazu. Słownik języka polskiego PWN definiuje wyobrażenie jako „wywołany w świadomości obraz przedmiotu, osoby lub sytuacji”" Patrząc z takiej perspektywy, przychodzi na myśl refleksja, iż wyobrażenia to zbiór obrazów, charakterystycznych dla danej jednostki bądź wspólnoty, utrwalony na poziomie protorozumienia, co oznaczać może, iż mamy do czynienia z konstruktami wiary immanentnej. Podobny związek widoczny jest także w innych językach, przede wszystkim tych czerpiących z łaciny, w której imago oznacza „obraz, wizerunek”, a imaginatio „wyobraźnię". Jednakże podkreślić trzeba, iż obraz nabiera wartości narracyjnej dopiero wówczas, kiedy jego treści znane są odbiorcy ${ }^{9}$. Przenosząc tę prawidłowość na płaszczyznę zbiorową, nietrudno skonstatować, iż podstawowym warunkiem mówienia o kolektywnych obrazach lub wyobrażeniach jest istnienie wspólnych kodów interpretacyjnych, umożliwiających zgodność interpretacyjną. Innymi słowy, mity, stereotypy, pamięć zbiorowa wymagają jedności umysłowej grupy na poziomie ideologii albo protoideologii.

J. Le Goff, Historia i pamięć, Warszawa 2007, s. 154.

Ibidem, s. 192.

6 J. Żarnowski, Metamorfozy społeczne 3. Historia społeczna. Metodologia - ewolucja - perspektywy, Warszawa 2011, s. 40-47.

http://sjp.pwn.pl/szukaj/wyobra\%C5\%BCenie.html [dostęp: 3.02.2015].

8 Obraz to po angielsku i francusku image, po włosku immagine, po hiszpańsku imagen. Wyobraźnia odpowiednio: imagination, immaginazione, imaginación. Andrzej Szpociński zauważa, że w języku angielskim istnieją terminy picture i image. Picture odnosi się do kwestii estetycznych czy symbolicznego znaczenia, zaś image nie ma w polszczyźnie swojego odpowiednika i wskazuje na widok rzeczywisty bądź zapisany w wyobraźni (A. Szpociński, Wizualizacja pamięci społecznej, [w:] Pamięć zbiorowa jako czynnik integracji i źródło konfliktów, A. Szpociński (red.), Warszawa 2009, s. 228).

9 K. Prajzner, Narratologia w perspektywie badań medioznawczych, [w:] Perspektywy badań nad kulturą, R.W. Kluszczyński, A. Zeidler-Janiszewska (red.), Łódź 2008, s. 173. 
Przykładowo, negatywne sądy o polityce Władimira Putina czy Recepa Tayyipa Erdoğana na pewno spotkałyby się ze zrozumieniem w zbiorowościach - najogólniej mówiąc - przerażonych poczynaniami wyżej wymienionych polityków ale z pewnością trudno byłoby znaleźć płaszczyznę porozumienia podczas rozmów z przedstawicielami kręgów prorosyjskich czy protureckich, znajdujących się pod wpływem silnej kampanii informacyjnej Moskwy czy Ankary. Używając naukowej terminologii, można zatem powiedzieć, iż w takich sytuacjach ścierają się dwie różne formy wyobrażeń zbiorowych, co uniemożliwia komunikację międzygrupową, a ta uwaga powinna zainteresować komunikologów, bowiem dekonstrukcja przestrzeni zbiorowych może znacząco przysłużyć się analizie kanałów komunikacyjnych.

Trzeba jednak uściślić, iż polskie określenie wyobrażenia wprowadza pewien chaos, biorąc pod uwagę fakt, że Durkheim posługiwał się terminem représentations, który na angielski tłumaczy się jako representations. W literaturze przedmiotu występuje również termin collective imaginations, ale - choć wydaje się podobny - posiada inne znaczenie. Imaginations powstają bowiem samorzutnie, representations zaś są efektem kontekstu zewnętrznego. Zaletą polskiego słowa wyobrażenia jest bezsprzecznie jego etymologiczny związek z obrazem, jakiego nie ma w angielskim representations, tylko że dla osób niezaznajomionych z tematyką taka rozbieżność budzi dodatkowe utrudnienia. Autorka spotkała się z różnymi propozycjami tłumaczenia pojęcia wprowadzonego przez Durkheima, jak np. reprezentacje czy przedstawienia, choć nasuwa się sugestia, iż nie są one do końca satysfakcjonujące jako metafory. Możliwe, że propozycje określenia représentations mianem przedstawień wynikają z wzorowania się na piśmiennictwie niemieckim, gdzie mówi się o kollektive Vorstellungen. Tym bardziej, że niemiecka nauka, przede wszystkim socjologia, poświęca dużo miejsca temuż pojęciu.

Jak zauważyliśmy na wstępie, wyobrażenia zbiorowe są kategorią dotąd raczej słabo rozpoznaną, szczególnie w odniesieniu do politologii. Autorka - pomimo długich poszukiwan - nie spotkała się z propozycją opisania ich struktury, a przecież każda kategoria wymaga zdefiniowania i określenia, dlatego za zasadne możemy uznać pytanie, co właściwie wchodzi w skład wyobrażeń zbiorowych. Wydaje się, że można je opisać jako zbiór elementów, takich jak: 1) mity i stereotypy; 2) pamięć zbiorowa; 3) tożsamość zbiorowa; 4) system aksjonormatywny (wraz z kulturą, religią i tradycją); 5) zbiorowe emocje, pomiędzy którymi zachodzą wzajemne oddziaływania o charakterze sprzężeń zwrotnych.

Oczywiście, niniejsza próba naszkicowania konstrukcji wyobrażeń zbiorowych ma charakter wstępny i zapewne znajdą się liczni badacze postulujący doskonalsze objaśnienia. Bardzo możliwe, iż niektórzy będą zaskoczeni 
potraktowaniem stereotypów jako odrębnej od mitów składowej wyobrażeń. Koncepcja ujmowania mitów i stereotypów jako jednego podsystemu wynika z przekonania, iż stereotyp jest szczególną postacią mitu i jako taki powinien być traktowany. Mniej kontrowersji wydaje się budzić pamięć zbiorowa, gromadząca coraz więcej entuzjastów, również na gruncie polskim, o czym poniżej będzie szerzej mowa. Wątpliwości wywoływać może włączenie kultury, religii i tradycji do szerszej całości - systemu aksjonormatywnego, bowiem te kategorie z powodzeniem mogłyby (a może i nawet powinny) być rozpatrywane odrębnie. Decyzja o scaleniu ich w jeden komponent motywowana była optyką politologiczną, a więc zainteresowaniem wpływem wyobrażeń zbiorowych na życie polityczne. Koncentrując się przede wszystkim na wartościach, konieczne jest szczególne uwzględnienie ich umocowań w kulturze, religii czy tradycji. Innymi słowy, kulturę, religię i tradycję należy potraktować jako determinanty norm, postaw, wartości, zachowań. Zapewne takie politologiczne, a więc świeckie podejście spotka się z krytyką, np. ze strony teologów, ale przecież odmienne nauki mogą, a czasami nawet powinny cechować różne stanowiska. Zresztą wybitny myśliciel protestancki Paul Tillich czynił znak równości pomiędzy religią a kulturą ${ }^{10}$.

Istotne jest przy tym podkreślenie, że żaden $\mathrm{z}$ wymienionych elementów nie zostaje pozostawiony sam sobie, ale zachodzą między nimi liczne interakcje o charakterze sprzężeń zwrotnych. Przykładowo, mity oddziałują na pamięć zbiorową, będąc jednocześnie jej składową, pozostają zakorzenione w tradycji, są efektem utwierdzonych w danej kulturze norm, często fundowane są na pierwiastku religijnym. $Z$ drugiej strony, zauważyć możemy mechanizmy przeciwne, pamięć zbiorowa utrwala mity, koryguje je w zależności od zmieniających się realiów albo podejmuje próby demityzacji. Mity są również nośnikami wartości, odgrywają kluczową rolę w religiach (tak transcendentnych, jak i obywatelskich). Jeśli więc między komponentami wyobrażeń zbiorowych zachodzi tak wiele związków, nasuwa się pytanie, czy trafne jest mówienie o sprzężeniach zwrotnych czy może lepszym określeniem byłby termin np. osmoza, tyle tylko, że osmoza zachodzi w jednym kierunku, a w analizowanym przypadku relacje przebiegają dwupłaszczyznowo. Innym przychodzącym na myśl terminem wydaje się dyfuzja, ale i tu pojawia się nieścisłość, gdyż dyfuzja to proces samorzutny, a reakcje zachodzące pomiędzy poszczególnymi elementami wyobrażeń zbiorowych nie są przypadkowe, stanowią rezultat mozolnej pracy dysponentów władzy symbolicznej. To po raz kolejny unaocznia konieczność

\footnotetext{
10 A. Máte-Tóth, M. Vukoja, Uloga katoličke Crkve u konstrukcijiidentiteta u multireligijskomdruštvu, [w:] Bosna i Hercegovina - Europsjkazemlja bez ustava. Znastveni, etički i političkiizazov, M. Džolan (red.), Sarajevo 2013, s. 59.
} 
dopracowania aparatu pojęciowego, pokazuje, iż zagadnienie wyobrażeń zbiorowych stanowi otwarte pole do interdyscyplinarnej debaty.

Badania nad wyobrażeniami zbiorowymi od lat fascynują badaczy francuskich, przede wszystkim reprezentujących kolejne generacje szkoły Annales. Podobnie wygląda sytuacja w innych krajach Europy Zachodniej, a także w Rosji i na Bałkanach, o czym pośrednio wspomina Marta Chaszczewicz-Rydel, pisząc o imagologii, a więc studiach nad przedstawianiem obcych w tekstach ${ }^{11}$. Rzeczoną imagologię rozumieć można jako obszar wyobrażeń zbiorowych, na płaszczyźnie których wyartykułowana przez wrocławską slawistkę prawidłowość znajduje również swoje przełożenie.

W wielokulturowym świecie szczególnego znaczenia nabierają zagadnienia pozostające w ścisłym związku z refleksją o wyobrażeniach zbiorowych, jak np. procesy stereotypizacji, mityzacji, budowania tożsamości grupowej w oparciu o pozycję my/oni. Nie dziwią więc wieloaspektowe dociekania na wspomniane tematy, które jednakże częściej stają się udziałem socjologów, etnologów, antropologów, historyków czy filologów niż politologów. Od 1983 r. University of California Press wydaje interdyscyplinarne pismo „Representations”, w którym ukazują się teksty z obszarów różnych nauk społecznych, przede wszystkim z literaturoznawstwa, historii, historii sztuki, antropologii, socjologii.

Nasuwa się sugestia, że przyczyną słabego zainteresowania polskich badaczy wyobrażeniami zbiorowymi może być etniczna i religijna homogeniczność naszego narodu, ale i to się powoli zmienia, bowiem przeobrażenia o charakterze globalnym oraz członkostwo w Unii Europejskiej sprawiają, że polska nauka nie może pozostać obojętna na światowe trendy. Ponadto, wydaje się, że otwarcie się politologii na sferę wyobrażeń może ją w znaczny sposób wzbogacić, tym bardziej, że jeśli najważniejszym zadaniem tej nauki ma być wyjaśnianie, to skomplikowany świat polityki wymaga, by było to wyjaśnianie kompleksowe, oparte na szerokiej wiedzy humanistycznej i mające praktyczny wymiar, o czym bardzo często się zapomina na różnych poziomach refleksji. Dlatego rację mają Barbara Krauz-Mozer oraz Paweł Ścigaj, pisząc, iż nie da się zamknąć politologii w ścisłych granicach, bowiem wielopoziomowość zjawisk społecznych, w tym również politycznych, rodzi konieczność patrzenia z różnych perspektyw ${ }^{12}$. Mirosław Karwat wskazuje natomiast, że dla zrozumienia „formalnej oprawy polityki” konieczne jest zwrócenie uwagi m.in. na: kontekst

11 M. Chaszczewicz-Rydel, Obrazy Bałkanów. Mity, stereotypy, nowa imagologia, Wrocław 2013, s. 42, 49.

12 B. Krauz-Mozer, P. Ścigaj, Sklep z podróbkami? Podejścia badawcze i metodologie w nauce o polityce, [w:] Podejścia badawcze i metodologie w nauce o polityce, B. Krauz-Mozer, P. Ścigaj (red.), Kraków 2013, s. 12-13. 
ideologiczny, symboliczny, cywilizacyjny, kulturowy oraz na działania zbiorowe, bowiem to one przekształcają się w ruchy polityczne ${ }^{13}$.

Zresztą pewne próby otwierania się politologii na wyobrażenia zbiorowe są w ostatnim czasie podejmowane, choć badacze zazwyczaj nie zajmują się całością wyobrażeń, ale raczej ich wybranymi segmentami, jak np. pamięć zbiorowa, mity, stereotypy, tożsamość zbiorowa.Tematykę przestrzeni zbiorowych uczynił centrum swoich zainteresowań Andrzej Sepkowski, tłumacząc, iż w poszukiwaniu „dobrych wyjaśnień” politolog powinien mieć także na uwadze „wolę, projekcje i emocje jednostek i zbiorowości” ${ }^{14}$.

Kwestie mitów i stereotypów od lat interesowały antropologów, etnologów, czy filozofów, w ostatnim czasie coraz częściej przyglądają się im reprezentanci socjologii czy politologii, co raczej nie dziwi, biorąc pod uwagę oddziaływanie mitów i stereotypów na sferę polityki. Rację ma Bohdan Szklarski, pisząc, iż „spojrzenie na politykę przez symbole i mity przywraca sferze publicznej całościowy wymiar" ${ }^{15}$. Badaczy pierwiastków politycznych interesuje przede wszystkim obecność mitów w przestrzeni publicznej, odwoływanie się do nich $\mathrm{w}$ programach politycznych, wykorzystanie ich przez polityków do zapewnienia poparcia dla swoich działań. Wydaje się, że mity są również nie mniej przydatne w nauce o stosunkach międzynarodowych czy popularnej w ostatnich latach securitologii, która nie może zamykać się do kwestii twardego bezpieczeństwa. Softpower czy kampanie informacyjne są przecież przesiąknięte gąszczem mitów, a ich rytualizacja zapewnić ma upowszechnienie określonych treści. Również więc i w tych przypadkach podejście jakościowe może być bardzo przydatne, na co zwraca uwagę chociażby amerykański politolog Marc Howard Ross, podkreślając naukową istotę, odwołujących się do zbiorowych emocji, ideologicznych „opakowań” konfliktów politycznych ${ }^{16}$. Anthony D. Smith spostrzegał natomiast, iż mity nie stanowią wyłącznie instrumentów dla przywódców w danym okresie, ale „są potężnymi znakami i sposobami wyjaśniania, mają zdolności generowania emocji w kolejnych pokoleniach, a także rozpalają moc wykraczającą poza ich »racjonalne« wykorzystanie, które elity i badacze społeczni uważają za odpowiednie"17. Wielu badaczy przestrzeni kolektywnych mawia, iż jeśli chcemy bliżej poznać daną zbiorowość,

13 M. Karwat, Metawiedza, esencja, forma, pragmatyka - cztery płaszczyzny badań teoriopolitycznych, [w:] B. Krauz-Mozer, P. Ścigaj (red.), op. cit., s. 62-63.

14 A. Sepkowski, Zbawić się na ziemi. O soteriologii immanentnej, Łódź 2014, s. 9.

15 B. Szklarski, W poszukiwaniu współczesnych powinowactw antropologii i polityki, [w:] Mity, symbole i rytuały we współczesnej polityce, B. Szklarski (red.), Warszawa 2008, s. 11.

16 M.H. Ross, Cultural Contestation in Ethnic Conflict, Cambridge 2007, s. 15.

17 A.D. Smith, Etniczne źródła narodów, Kraków 2009, s. 299. 
powinniśmy zdekonstruować jej przestrzenie mityczne i wydaje się, że ta uwaga powinna zainspirować także politologów.

Pamięć zbiorowa - kiedyś zarezerwowana wyłącznie dla historyków - staje się dziś przedmiotem interdyscyplinarnej debaty (również politologicznej), zwłaszcza, że w ostatnim czasie zapanowała moda na zainteresowanie pamięcią. Chris Lorenz mówi o memory boom ${ }^{18}$, inni o zwrocie pamięciowym (Mnemonicturn). Na świecie coraz większą popularnością cieszą się interdyscyplinarne memory studies, taki też tytuł nosi ukazujący się od 2008 r. periodyk, w którym publikowane są teksty przedstawicieli różnych dyscyplin naukowych.

$\mathrm{W}$ Polsce niekwestionowanym autorytetem $\mathrm{w}$ politologicznych dociekaniach na temat pamięci zbiorowej jest Anna Wolff-Powęska. Poznańska badaczka zaznacza, iż pamięć zbiorowa nigdy nie występuje w czystej postaci, że podlega polityzacji ${ }^{19}$, potwierdzając, że powinni się nią zajmować również politolodzy. Zresztą, przyglądając się polskiemu piśmiennictwu politologicznemu, możemy zauważyć szerokie zainteresowanie tą tematyką, co sprawia, iż spośród analizowanych komponentów systemu wyobrażeń zbiorowych pamięć zbiorowa zdaje się tym najlepiej rozpoznanym i najszerzej opisanym. Pomimo tak rozległych badań nie została dotąd wypracowna wspólna terminologia, co podkreślają również Magdalena Saryusz-Wolska i Robert Traba w przedmowie do wydanego pod ich redakcją leksykonu kultury pamięci ${ }^{20}$.

Warto również wspomnieć o inicjatywie związanego $\mathrm{z}$ wydawnictwem Adam Marszałek PPSY (The Polish Political Science Yearbook) seminarium Remembrance and Political Transitions, odbywającego się w Toruniu we wrześniu 2016 roku, w którym autorka prezentowanego tekstu miała przyjemność uczestniczyć. Organizatorzy rzeczonego spotkania, zdając się rozumieć aktualne, światowe trendy w naukach politycznych, zapowiedzieli, iż planują zorganizowanie całej serii podobnych sympozjów, gdzie klamrą spajającą stanie się kwestia pamięci zbiorowej.

Ożywiona, interdyscyplinarna debata toczy się również wokół zagadnienia tożsamości zbiorowej, co zdaje się oczywistą konsekwencją kondycji człowieka ponowoczesnego. W ostatnim czasie zagadnienie to przestało być wyłącznie domeną socjologów, psychologów, etnologów czy badaczy kultury, ale zaczęli się nim interesować również politologowie. Francuski politolog, Dominique

18 C. Lorenz, Unstuck the Time. Or: the Sudden Presence of the Past, [w:] Performing the Past: Memory, History, and Identity in Modern Europe, K. Tilmans, F. van Vree, J. Winter (red.), Amsterdam 2010, s. 83.

19 A. Wolff-Powęska, Pamięć - brzemię i uwolnienie. Niemcy wobec nazistowskiej przeszłości (1945-2010), Poznań 2011, s. 77.

20 M. Saryusz-Wolska, R. Traba, Wprowadzenie, [w:] Modi memorandi. Leksykon kultury pamięci, M. Saryusz-Wolska, R. Traba (red.), Warszawa 2014, s. 14-19. 
Moïsi w przełomowej pracy Geopolityka emocji, przyznającej zbiorowym emocjom status pełnoprawnego podejścia badawczego, skonstatował, że „wiek XXI będzie wiekiem tożsamości”21. Podobnych antycypacji pojawia się znacznie więcej. Serbski politolog Milenko Marković mówi np. o zwrocie od polityki interesów ku polityce tożsamości ${ }^{22}$. I nawet jeśli takie sądy uznamy za zbyt śmiałe, bowiem w politologii ciągle prymat wiodą tzw. obszary twarde, do których zalicza się m.in. kwestie bezpieczeństwa, to jednak przyznać trzeba, iż pytanie o tożsamość, a właściwie jej różne postaci, stanie się również wyzwaniem dla badaczy świata polityki.

Mamy tu na myśli z jednej strony indywidualną tożsamość decydentów politycznych, ale $\mathrm{z}$ drugiej przede wszystkim interesująca wydaje się tożsamość zbiorowa, zarówno wielkich zbiorowości, jak i poszczególnych grup społecznych. Odpowiedzi na pytanie kim jesteśmy okazują się być bardzo pomocnymi przy badaniu preferencji politycznych, szczególnie jeśli weźmiemy pod uwagę społeczeństwa wieloetniczne czy wielokulturowe. Odmienna tożsamość może generować tendencje separatystyczne, stąd powinna budzić zainteresowanie badaczy etnopolityki. Poczucie zagrożenia własnej tożsamości potrafi wyzwalać niechęć do obcych, co obserwujemy w dzisiejszym świecie Zachodu. Ale tożsamość zbiorowa posiada nie tylko charakter wykluczający, może ona również być rozpatrywana $\mathrm{z}$ punktu widzenia łączenia ponad podziałami, budowania szerokiej, inkluzyjnej płaszczyzny autoidentyfikacji. Nic więc dziwnego, iż w dobie procesów globalizacyjnych i imigracyjnych zagadnienia tożsamości zaczynają fascynować również politologów.

Tożsamość określić można jako podstawowy filar spajający daną grupę, pozwalający jej zdefiniować samą siebie. Małgorzata Dziekanowska podkreśla, że tożsamość zbiorowa „ma charakter dyskursywny, istnieje jako obraz My, który jest konstruowany i podzielany przez jej członków"23. Badaczka daje do zrozumienia, że tożsamość ma charakter wyobrażeniowy, że jest ona po prostu zbiorem opowieści, przekonań, narracji na temat samych siebie. Wynika z tego, że tożsamość jest - podobnie jak cały system wyobrażeń zbiorowych - przede wszystkim kwestią wiary, bowiem członkowie wspólnoty podzielają analogiczne mniemanie o tym, kim są, a więc, innymi słowy, wierzą w te same treści, np. o wyjątkowości własnego narodu.

21 D. Moïsi, Geopolityka emocji. Jak kultury strachu, upokorzenia, nadziei przeobrażaja świat, Warszawa 2012, s. 35.

22 M. Marković, Ogledi o nacionalnom i demokratskompitanju. Postjugoslovenski slučaj Srbije, Beograd 2010, s. 72.

23 M. Dziekanowska, Pamięć a tożsamość zbiorowa, [w:] Pamięć jako kategoria rzeczywistości społecznej, J. Styk, M. Dziekanowska (red.), Lublin 2012, s. 31. 
Jak zostało wcześniej wspomniane, pomiędzy poszczególnymi elementami systemu wyobrażeń zbiorowych zachodzą wzajemne interakcje. Można byłoby wiele pisać na temat związków mitów, stereotypów czy pamięci zbiorowej z zagadnieniem tożsamości, co dogłębnie analizuje Anna Wolff-Powęska ${ }^{24}$. Trywializmem będzie stwierdzenie, iż w procesie definiowania siebie najłatwiej odnosić się do tego, co było. Nie tylko socjologowie zauważają, iż ujednolicona pamięć stanowi podstawę budowania zbiorowej tożsamości ${ }^{25}$. Tragicznie zmarły niemiecki znawca przestrzeni kolektywnych nazwał wspólnotę pamięci jednym z najważniejszych kulturowych fundamentów identyfikacji grupowej ${ }^{26}$. W każdym społeczeństwie musi panować zgoda co do pewnych obrazów przeszłości i systemu wartości umożliwiającego ich interpretację, a istnienie takich matryc interpretacyjnych stanowi o tożsamości grupowej.

Wartości grupowe to kolejny $\mathrm{z}$ wymienionych przez nas elementów wchodzących w skład większej całości, jaką są wyobrażenia zbiorowe. W socjologii od czasów Durkheima podkreśla się, że normy pozostają w ścisłym związku z wyobrażeniami zbiorowymi i tego poglądu nie kwestionowały kolejne szkoły badawcze ${ }^{27}$. System aksjonormatywny definiuje się jako układ norm i wartości charakterystycznych dla danej zbiorowości, a w ramach niego wyróżnia się najczęściej takie elementy jak: zwyczaje, moralność, prawo, modę i estetykę. Oczywiste jest więc, iż system ten pozostaje w ścisłym związku z kulturą i religią, bo to one przecież wpływają na ogólnie przyjęte zasady postępowania. Dlatego właśnie autorka proponuje, aby pierwiastki kulturowy i religijny rozpatrywać w połączeniu $\mathrm{z}$ aksjonormatywnym. Warto uwypuklić, iż sfera wartości pozostaje $\mathrm{w}$ ścisłych relacjach $\mathrm{z}$ innymi elementami systemu wyobrażeń zbiorowych. Jak pisze Magdalena Ślawska, wartości są najczęściej przedstawiane poprzez mityczne opowieści o walce dobra ze złem, co wpływa na nasz sposób interpretacji rzeczywistości ${ }^{28}$. Wystarczy przypomnieć, iż mity opisują rzeczywistość wedle czarno-białej matrycy, a więc tym samym projektują one

24 A. Wolff-Powęska, op. cit., s. 53-60.

25 E. Breslavskaia, P. Załęski, Tradycja w polityce historycznej i symbolach politycznych niepodległego Kirgistanu, [w:] Tożsamości narodowe na obszarze postradzieckim. Między dziedzictwem a tradycja wynalezioną, P. Załęski, E. Breslavskaia, M. Włodarkiewicz (red.), Warszawa 2012, s. 79; H. Hein, Historische Mythos- und Kulturforschung, [w:] „Mythos”, no. 2: Politische Mythen, t. 2, P. Tepe (red.), Würzburg 2006, s. 45.

26 W. Spohn, National Identities and Collective Memory in an Enlarged Europe, [w:] Collective Memory in the Enlarging Europe: The Effects of Integration and Enlargement, K. Eder, W. Spohn (red.), Abington-on-Thames 2005, s. 2.

27 G. Mikl-Horke, Soziologie: Historischer Kontext und soziologische Theorie-Entwürfe, München 2011, s. 397.

28 M. Ślawska, Proza autobiograficzna pokolenia jugonostalgików, Wrocław 2013, s. 210-215. 
przestrzeń aksjologiczną. Krzysztof Śnieżyński wskazuje na związek aksjologii z pamięcią zbiorową, bowiem to pamięć przechowuje wartości i mówi, jak należy je realizować ${ }^{29}$. Wartości kształtują także tożsamość oraz generują emocje.

Nadto, trzeba podkreślić kolejną oczywistość, mianowicie to, że wartości i normy postępowania - jak całość wyobrażeń zbiorowych - są zmienne w czasie, czego świadomość ma chyba każdy patrzący na standardy obowiązujące w bliższej i dalszej przeszłości, a to spostrzeżenie można odnieść do wszystkich dziedzin życia. Janusz Mariański wyjaśnia z perspektywy socjologicznej, że układ norm stanowi konstrukcję społeczną, a te z natury rzeczy mają charakter zmienny ${ }^{30}$.

Przykłady potwierdzające owo spostrzeżenie można by długo wymieniać. Zwróćmy chociażby uwagę, iż kiedyś prawa wyborcze zarezerwowane były wyłącznie dla mężczyzn i to nie dla wszystkich, skoro w Anglii czy Francji istniał cenzus majątkowy, zaś dzisiaj zastanawiamy się nad parytetami dla kobiet na listach partyjnych. Francis Fukuyama mówi nawet o postępującej feminizacji życia politycznego ${ }^{31}$. Z kolei Peter Singer, australijski etyk i znany obrońca praw zwierząt konstatuje, że w ostatnich 25 latach XX wieku nastąpiła znacząca zmiana, jeśli chodzi o stosunek człowieka do cierpienia innych istot żywych, szczególnie w świecie Zachodu, co przekłada się na konkretne decyzje polityczne, np. unijne przepisy dotyczące warunków panujących w hodowlach ${ }^{32}$. Nietrudno zauważyć, iż zmiany w normach prawnych są wynikiem przemian społecznych i transformacji sfery aksjonormatywnej. Można więc zapytać, czy skuteczne może być przestrzeganie tzw. światowych standardów, skoro systemy wartości mogą się różnić nawet w bardzo znacznym stopniu. Tym bardziej, że te „światowe standardy” wyznacza Zachód, pod wieloma względami tak odmienny od reszty globu. Mając to na uwadze, łatwiej zrozumieć, dlaczego zawodzą próby przeszczepiania demokracji czy egzekwowania przestrzegania praw człowieka.

W tym miejscu dochodzimy do pytania o procesy modernizacyjne, których naturalną konsekwencją są zamiany kształtów wyobrażeń zbiorowych. Andrzej Jabłoński podkreśla, że modernizacja to złożony proces przechodzenia od społeczeństwa tradycyjnego do nowoczesnego, który przebiega na trzech

${ }^{29}$ K. Śnieżyński, Pamięć religijna jako akt lojalności względem świata, [w:] Pamięć - kultura-edukacja, A.B. Bieś, M. Chrost, B. Topij-Stempińska (red.), Kraków 2011, s. 12.

30 J. Mariański, Świadomość moralna Polaków w procesie przemian - główne tendencje, [w:] Style życia, wartości, obyczaje. Stare tematy, nowe spojrzenia, A. Jawłowska, W. Pawlik, B. Fatyga (red.), Warszawa 2012, s. 104.

31 F. Fukuyama, Polityka kobiet, [w:] Prognozy. Trzydziestu myślicieli o przyszłości, S. Griffiths (red.), Poznań 2006, s. 139.

32 P. Singer, Nowa etyka, [w:] S. Griffiths (red.), op. cit., s. 273. 
płaszczyznach: społeczno-ekonomicznej, kulturowej i politycznej. Przy czym, jak słusznie zauważa autor, teorie modernizacji budzą dziś spore kontrowersje, zarzuca im się patrzenie na innych z zachodniego punktu widzenia ${ }^{33}$. Dlatego coraz częściej badacze podkreślają, iż modernizacja wcale nie powinna oznaczać westernizacji. Popularnością cieszy się teoria systemów-światów, kojarzona przede wszystkim z Immanuelem Wallersteinem i - co ważne z punktu widzenia wyobrażeń zbiorowych -pozostająca w ścisłym związku z dorobkiem szkoły Annales, choć i ona bywa krytykowana za zbyt daleko idące uproszczenia ${ }^{34}$.

W literaturze często spotkać można pogląd, iż system aksjonormatywny reguluje zachowania zarówno jednostek, jak i zbiorowości. Nie sposób nie zauważyć, że postawy jednostek warunkowane są normami przyjętymi w danej zbiorowości i to w danym momencie, tak więc to im przyznać należy najważniejsze znaczenie. Podobne stanowisko zdaje się prezentować Paweł Łyżwa, stwierdzając, iż „polityka, będąc fragmentem życia społecznego, jest równocześnie częścią określonej rzeczywistości kulturowej, ta natomiast w znacznym stopniu jest determinowana przez wartości dla niej centralne" ${ }^{\prime 35}$.

Niemiecki etnolog Klaus Roth, zastanawiając się nad przemianami w systemach wartości społeczeństw Europy Południowo-Wschodniej, mówi o modernizacji fasadowej, polegającej na selektywnym przyjmowaniu wybranych zachodnich obyczajów, zasad i zdobyczy cywilizacyjnych ${ }^{36}$, czemu jednak nie towarzyszą transformacje w sferze mentalnościowej. Innymi słowy, tamtejsze procesy adaptacji zachodnich trendów mają jedynie charakter powierzchowny, a sfera aksjonormatywna jest na nie bardzo odporna. Wydaje się, że te spostrzeżenia można z powodzeniem rozszerzyć na inne obszary globu. Choć jednym ze skutków globalizacji jest przyjmowanie zachodniego stylu życia, to przecież otwieranie restauracji należących do sieci McDonald's czy lokowanie filii korporacji międzynarodowych nie oznacza przyjęcia w pełni zachodnich standardów. Demonstracyjne eksponowanie postępowego stylu życia ma zazwyczaj charakter powierzchowny i nie przekłada się na westernizację sfery aksjonormatywnej.

Kategoria systemu aksjonormatywnego zdobyła uznanie przede wszystkim na gruncie socjologii, gdzie od lat z powodzeniem rozwija się dyscyplina zwana socjologią moralności. Poczęli jej się przyglądać również reprezentanci innych

33 A.W. Jabłoński, Teorie i podejścia w badaniach zmiany systemów politycznych, [w:] B. Krauz-Mozer, P. Ścigaj (red.), op. cit., s. 80, 82.

34 N. de Deugt, H.W. Hoen, Dovetailing Economics and Political Science, Assen 2010, s. 54.

35 P. Łyżwa, Aksjologiczne uwarunkowania polityki jako sfery społecznej - zarys problematyki, „Wrocławskie Studia Politologiczne” 2012, nr 13, s. 25.

36 K. Roth, Slike u glavama. Ogledi o narodnoj kultury u jugoistočnoj Evropi, Beograd 2000, s. $230-234$. 
nauk: psychologów i pedagogów interesuje wykorzystanie wartości w procesie edukacji, etnologowie koncentrują się na wartościach uwidaczniających się w kulturze, filolodzy badają ich obecność w tekstach literackich. Systemem aksjonormatywnym zaczęli się interesować również politologowie. Pomimo iż $\mathrm{w}$ politologii ciągle zaznacza się tendencja do traktowania polityki jako gry wielkich interesów, prowadzonej przez wytrawnych graczy, kierujących się „pragmatyzmem”, a nie pierwiastkiem aksjologicznym, to coraz więcej badaczy dostrzega, iż politycy to nierzadko ludzie posiadający swój system wartości, który nie pozostaje bez wpływu na ich decyzje. Ziemowit Pietraś, badając typy analizy decyzyjnej, wyróżnia m.in. typ aksjologiczny, od dawna postulowany i coraz szerzej rozwijany w postzimnowojennym świecie. Zakłada on, „że decyzje polityczne są przede wszystkim funkcją zaakceptowanego przez decydentów systemu wartości ideologicznych, politycznych czy moralnych, a cele działania polityków stanowią bezpośrednią funkcję afery aksjologicznej”37.

Trzeba także pamiętać, że politycy zazwyczaj przynależą do konkretnych partii, a te przecież odwołują się do określonych wartości, budują na nich swoje programy, choć znakiem naszych czasów staje się zjawisko zacierania się wyrazistości ideologicznej ugrupowań politycznych, co owocuje powstawaniem tzw. partii władzy. Nadto, elity polityczne przechodzą weryfikację w procesie wyborów, tak więc ich wypowiedzi i działania muszą pozostawać w zgodzie z profilem aksjologicznym elektoratu. Nie ma chyba demokratycznego społeczeństwa, w którym nie toczyłby się debaty o wymiarze aksjologicznym, by wymienić chociażby takie kwestie, jak kara śmierci, aborcja czy eutanazja i można nawet wysunąć przypuszczenie, że zagadnienia o charakterze światopoglądowym są jednymi $z$ najżywiej dyskutowanych; za ich pomocą łatwo tworzyć i umacniać społeczne podziały, co politycy skwapliwie wykorzystują w sytuacji, kiedy zachodzi potrzeba odwrócenia uwagi od innych problemów.

Jerzy Sielski w pracy Pierwotne kategorie aksjologicznej analizy decyzyjnej, stanowiącej ciekawą próbę wykazania przydatności refleksji nad wartościami w wyjaśnianiu procesu podejmowania decyzji politycznych, dowodzi, iż decyzja polityczna pozostaje $\mathrm{w}$ bezpośrednim związku $\mathrm{z}$ racjonalnością aksjologiczną, poprzez którą badacz rozumie charakterystyczną dla decydenta „racjonalność", wynikającą z przyjętej przez niego hierarchii wartości ${ }^{38}$. Zdaniem autora, decydent staje wobec konieczności dokonania wyboru pomiędzy dwoma różnymi relacjami preferencji: własnego systemu wartości oraz układów politycznych i ma on do wyboru trzy rozwiązania: kierowanie się racjonalnością aksjologiczną (a więc wartościami), podmiotową (czyli interesem grupo-

37 Z.J. Pietraś, Decydowanie polityczne, Warszawa 2011, s. 24.

38 J. Sielski, Pierwotne kategorie aksjologicznej analizy decyzyjnej, Katowice 1997, s. 9. 
wym lub osobistym) oraz pragmatyczną (w sytuacji kiedy decydent potrafi pogodzić obie kategorie) ${ }^{39}$.

Aksjologia odgrywa także istotną rolę w stosunkach międzynarodowych, gdzie wartości z jednej strony motywują do pewnych działań, z drugiej zaś służą do wyznaczania standardów ogólnocywilizacyjnych, do których odwołują się politycy i inni gracze w przestrzeni międzynarodowej ${ }^{40}$. Oczywiście, nie wszystkie działania można wyjaśnić w oparciu o kierowanie się wartościami, a co więcej, takie podejście wielu mogłoby uznać za naiwne. Jeśli jednak główną osią politologii ma być funkcja eksplanacyjna, to analiza rzeczywistości musi uwzględniać rozliczne perspektywy, w tym pogląd, że państwa w swojej polityce zagranicznej dążą m.in. do upowszechniania własnych wartości. W bardzo wielu przypadkach to jedynie pusty slogan, przy pomocy którego próbuje się wytłumaczyć społeczeństwu konkretne działania, tak jak było to w przypadku interwencji NATO w 1999 roku w Jugosławii, kiedy mówiono o pierwszej w historii wojnie w obronie praw człowieka, co Paul Johnson komentował słowami: „Uważam, że wola obrony praw człowieka jest dziś największą polityczną ideą na skalę światową"41. Gdyby jednak tak w istocie było, Sojusz Północnoatlantycki interweniowałaby bardzo często, w różnych regionach świata. Faktyczne motywacje musiały więc być rezultatem gry interesów mocarstw, niemniej jednak na uwagę zasługuje powoływanie się decydentów na szlachetne wartości wykorzystywane jednak w otoczce obłudy, będącej zwykle negacją wartości.

Przyglądając się literaturze politologicznej, można stwierdzić, iż bardzo wielu badaczy - z premedytacją lub nie - ociera się o sferę wartości. Nie sposób wyszczególnić w tym miejscu nieskończenie długiej listy zagadnień, których analiza zmusza autorów do pochylenia się nad wątkami aksjologicznymi, dla porządku wymienić można chociażby: społeczeństwo obywatelskie, kultura polityczna, myśl polityczna, ideologiczne profile partii politycznych, wielokulturowość.

Jak zostało zauważone, system aksjonormatywny powinien być rozpatrywany $\mathrm{w}$ połączeniu $\mathrm{z}$ religią i kulturą. Pierwiastek religijny stanowi jedną z najważniejszych osi podziałów cywilizacyjnych czy kulturowych. On w dużym stopniu sprawia, iż świat wyobrażeń mieszkańców krajów Zatoki Perskiej jest tak różny od zachodniego. Nawet jeśli zawęzić pole poszukiwań do Starego Kontynentu, trudno nie zauważyć, że kraje protestanckie pod wieloma względami różnią się od katolickich czy prawosławnych. Ale tłumaczenie różnic

39 Ibidem, s. 96-97.

40 J.K. Kołodziej, Wartości polityczne - problem badawczy dla politologa, [w:] B. Krauz-Mozer, P. Ścigaj (red.), op. cit., s. 197.

${ }^{41}$ P. Johnson, Prawie wszędzie widzę przesłanki do optymizmu, rozm. B. Wildstein, [w:] B. Wildstein, Profile wieku, Warszawa 2000, s. 91. 
wyłącznie czynnikiem religijnym może być mylące, o czym świadczy chociażby przykład polskich Tatarów, wspólnoty muzułmańskiej, ale na płaszczyźnie aksjonormatywnej bliskiej reszcie społeczeństwa. To spostrzeżenie pozwala sugerować, iż różnice cywilizacyjne są implikowane przede wszystkim pierwiastkiem kulturowym, którego religia jest ważną, ale tylko składową. Zwraca na to także uwagę Paul Ricœur, porównujący religię do języka ojczystego, który jednostka nabywa automatycznie wraz z całą kulturową obudową ${ }^{42}$. W tym miejscu długo można byłoby wykazywać wzajemne relacje kultury i religii, ale autorka, będąc politologiem, a nie ekspertem od spraw kultury, nie posiada odpowiedniego warsztatu, by podejmować się takiej refleksji.

Jak wielokrotnie podkreślaliśmy, system wartości bywa w znaczącym stopniu determinowany przez kulturę. Wystarczy nadmienić, iż od początku istnienia wspólnot archaicznych tożsamość zbiorowa była konstruowana w oparciu o zespół mitów, które jednocześnie określały system wartości, pielęgnowały pamięć o przeszłości, a zarazem - co nas w tym miejscu szczególnie interesuje - stanowiły kompleks kulturowy zbiorowości. Trywializmem będzie osąd, iż szeroko rozumiana kultura określa kształty wyobrażeń zbiorowych i jako taka powinna być brana pod uwagę przy refleksjach na temat tej kategorii.

W literaturze pojawiają się rozliczne propozycje klasyfikacji kultury, co zdaje się być wynikiem rosnącego zainteresowania wspomnianą tematyką ze strony reprezentantów różnych nauk społecznych i humanistycznych. Według jednego z najbardziej klasycznych rozróżnień, wydziela się kulturę materialną i niematerialną, przy czym nas szczególnie interesuje ta druga. Pod terminem „kultura niematerialna” rozumie się zarówno kulturę duchową, symboliczną, jak i wartości, schematy zachowań oraz percepcji świata. Oznacza to, że mówimy o pojęciu niezwykle szerokim, obejmującym „całościowy kompleks rozmaitych obszarów, zjawisk, praktyk i zachowań, aspektów i wymiarów, wzorów i symboli" 43 .

Dla badacza przestrzeni zbiorowych szczególnie istotny jest fakt, iż kultura wyznacza kanon wspólnych wierzeń, wyobrażeń, obrazów i uprzedzeń, które przekazywane są kolejnym pokoleniom ${ }^{44}$, co znawcy przedmiotu nazywają reprodukowaniem kultury. To stanowi o jej ogromnej sile, skoro otacza ona człowieka od pierwszych jego dni. Kulturę definiuje się także jako wytwór

42 P. Ricoeur, Żyć a ż do śmierci oraz fragmenty, Kraków 2008, s. 44.

${ }^{43}$ M. Hopfinger, Kultura: scalanie i wybór, [w:] R.W. Kluszczyński, A. Zeidler-Janiszewska (red.), op. cit., s. 23.

44 J. Assmann, Pamięć kulturowa, Pismo, zapamiętywanie i polityczna tożsamość w cywilizacjach starożytnych, Warszawa 2008, s. 153-154. 
zindywidualizowanych wyborów aksjologicznych ${ }^{45}$, co potwierdza zasadność rozpatrywania jej w ramach refleksji wokół systemu aksjonormatywnego.

Socjologowie używają pojęcia „enkulturacja” dla określenia procesu uczenia się i internalizowania wartości, norm i oczekiwań obowiązujących w danej wspólnocie. Ten proces można także tłumaczyć, używając terminologii Pierre’a Bourdieu, jako przemoc symboliczną, miękką formę odgórnego narzucania określonego sposobu percepcji rzeczywistości. Oznacza to, że jednostka, ucząc się kultury zbiorowości, w której przyszło jej żyć i się wychowywać, jednocześnie internalizuje system wyobrażeń zbiorowych w niej obowiązujący.

Jedna $\mathrm{z}$ rozlicznych definicji kultury określa ją jako wspólny system znaczeń ${ }^{46}$, co bardzo dobrze pokazuje jej związek z wyobrażeniami zbiorowymi. Na kwestię znaków i znaczeń szczególny nacisk kładą semiotycy. Wybitni przedstawiciele szkoły tartusko-moskiewskiej, Jurij Łotman i Boris Uspienski, traktując kulturę jako system znakowy, proponowali typologię kultur w oparciu o „stosunek do znaku i znakowości”" rowymi potwierdza często stosowana, a nawet chyba czasem zbyt nadużywana, metafora o zaprogramowaniu kulturowym, rozumianym jako odpowiednie ukierunkowanie umysłu, narzucenie mu określonych norm i zachowań. Oczywiście tego „zaprogramowania” czy „narzucania” nie wolno rozumieć negatywnie, bowiem skutkiem takiego procesu są wspólne schematy działań, zapewniające płaszczyznę porozumienia $\mathrm{w}$ ramach zbiorowości. Łatwo to zilustrować na przykładzie jednostek przenoszących się do obcych przestrzeni kulturowych, również tych nieodległych. Nawet najbardziej kosmopolitycznie zorientowane osoby odczuwają ulgę z powodu powrotu do swoich.

Andrzej de Lazari, Olga Nadskakuła i Magdalena Żakowska, pisząc o zaprogramowaniu kulturowym, porównują je do software umysłu, co wydaje się doskonale oddawać naturę fenomenu ${ }^{48}$. Zaprogramowanie oznacza działanie sił zewnętrznych, przez które rozumieć należy otaczające jednostkę środowisko. Nabyte w procesie enkulturacji normy zachowań i wzory postępowań przekładają się nie tylko na wyznawane wartości, ale również określają stosunek wobec

${ }^{45}$ A. Kapciak, Kultura nowoczesności a niepewność znaczeń, [w:] Spotkania z kultura. Antoninie Kłoskowskiej w piątą rocznicę śmierci, J. Kurczewska, E. Tarkowska (red.), Warszawa 2006, s. 48-49.

46 F. Trompenaars, Ch. Hampden-Turner, Siedem wymiarów kultury. Znaczenie różnic kulturowych $w$ działalności gospodarczej, Kraków 2002, s. 27.

47 J. Łotman, B. Uspieński, O semiotycznym mechanizmie kultury, [w:] Semiotyka kultury, wybór i opracowanie, E. Janus, M.R. Mayenowa, Warszawa 1977, s. 155.

48 Zaprogramowanie kulturowe - SOFTWARE naszego umysłu, [w:] Zaprogramowanie kulturowe narodów Europy, A. de Lazari, O. Nadskakuła, M. Żakowska (red.), Łódź 2007, s. 5. 
innych oraz nas samych. Mając to na uwadze, można zaryzykować spostrzeżenie, iż zainteresowanie politologów kulturą powinno wychodzić o wiele dalej aniżeli kultura polityczna, od dawna postrzegana jako jedna z podstawowych kategorii politologicznych.

W podobny sposób należy odnieść się do tradycji, kolejnego fenomenu poddawanego interdyscyplinarnej refleksji, a przy tym rzadko włączanego do politologicznych debat. A przecież tradycja jest nośnikiem pamięci, określa tożsamość, przy jej pomocy przekazywane są mity i stereotypy. We wspólnotach archaicznych, w których nie istniały środki masowego przekazu, to właśnie tradycji przypadło zadanie rytualizacji czy też reprodukowania mitów, stereotypów, norm, wartości.

Ale błędem byłoby twierdzenie, że znaczenie tradycji ograniczać trzeba jedynie do dawnych epok, bowiem również i dziś pełni ona istotną rolę, a ponadto pozostaje w ścisłym związku ze światem polityki, na co zwraca uwagę Dunja Rihtman-Auguštin, pisząc, iż obyczaje stanowią odzwierciedlenie aktualnej epoki i jej społecznych, kulturowych i politycznych realiów ${ }^{49}$. Badacze zajmujący się przestrzenią postkomunistyczną często sporo miejsca poświęcają procesom reorganizacji i dostosowywania tradycyjnych obrzędów i obyczajów do wymogów komunistycznej ideologii. I tak chociażby Vintilă Mihăilescu podkreśla, że narracje o „nowym człowieku”, choćby nie wiadomo jak bardzo radykalne, musiały zapewnić mu jakąkolwiek spuściznę, inaczej byłyby niepełne ${ }^{50}$. Niemożliwe jest przecież oderwanie się, wyparcie części biografii. Zdaniem Klausa Rotha, postępowanie państw zza żelaznej kurtyny nie było niczym nowym, bowiem przynajmniej od średniowiecza Kościół, a później państwo określały, co, kiedy i jak należy świętować. Specyfika komunistycznego projektu leżała natomiast w jego totalnej organizacji i szybkości upowszechniania rozwiązań uważanych za postępowe ${ }^{51}$. Tutaj nasuwa się spostrzeżenie, iż właśnie gwałtowne tempo przemian tradycji uznać można za jeden z czynników stanowiących o nieprzyjęciu się systemu, bo siła tradycji tkwi w przekonaniu o jej ciągłości i niezmienności.

Zauważyć jednak możemy za D. Rihtman-Auguštin, iż traktowanie tradycji i obyczajów jako czegoś starego, od zawsze obecnego w naszej kulturze jest jedynie złudzeniem, bowiem obyczaje nieustannie się zmieniają, dostosowując

49 D. Rihtman-Auguštin, Ulice moga grada. Antropologija domaćeg terena, Beograd 2000, s. 269.

50 V. Mihailesku, Svakodnevnicanijeviše ono što je bila. Beleške jednog balkanskog antropologa u doba tranzicije, Beograd 2002, s. 24.

51 K. Roth, Od socijalizma do Evropskeunije. Ogledi o svakodnevnom životu u jugoistočnoj Evropi, Beograd 2012, s. 245. 
się do wymogów aktualnych czasów ${ }^{52}$. Na tę kwestię wskazywali przed laty Eric Hobsbawm i Terence Ranger w słynnej pracy Tradycja wynaleziona, a ich spostrzeżenia odnieść można z powodzeniem nie tylko do wspólnot narodowych, o których pisali, ale również innych, np. lokalnych, czy ponadnarodowych. Jeśli dziś w dyskusjach o stworzeniu wspólnej, europejskiej tożsamości postuluje się konieczność wykreowania i rytualizowania nowych mitów, symboli, oznacza to de facto postulat „wynalezienia” nowej tradycji. Nie wydaje się, by taka próba powiodła się, jeśli pamiętamy fiasko projektu wspólnej europejskiej historii, o którym wstydliwie się milczy. Można nawet zaryzykować spostrzeżenie, iż projekt ów zamiast łączyć, tylko skłócił elity naukowe. Nic dziwnego, skoro wielu naukowców pozostaje zakładnikami nacjonalizmu metodologicznego, a więc patrzenia na przedmiot badań z punktu widzenia własnej nacji, jej interesów, doświadczeń i wyobrażeńn ${ }^{53}$.

Faktem jest, iż człowiek potrzebuje tradycji, a raczej potrzebuje wiary w to, że istnieją przekazywane z pokolenia na pokolenie treści, wartości, obyczaje, bowiem to sprawia, że łatwiej mu się odnaleźć w szybko zmieniającym się świecie. Jeśli jednym $\mathrm{z}$ wyznaczników postmodernizmu jest niespotykane dotąd tempo zmian, nietrudno zauważyć, że potrzeba oparcia się na tradycji wzrasta, bowiem ta usensownia egzystencję i zapewnia poczucie kontinuum.

Raczej nie ulega wątpliwości, iż wyobrażenia zbiorowe pozostają silnie związane ze sferą emocji i mamy tu na myśli przede wszystkim emocje kolektywne: strachy, nadzieje, oczekiwania, rozczarowania, upokorzenia. Jak na początku zauważyliśmy, emocje w polityce to nie tylko szczebel decydentów, ale także poziom mas. W latach 40. i 50. XX w., kiedy psychologia polityki dopiero zaczynała się kształtować, dominowało w niej podejście osobowościowe, a więc koncentrowano się na jednostce, motywach jej zachowań i działań. Tworzono liczne psychobiografie znanych przywódców, np. Woodrowa Wilsona czy Marcina Lutra, albo badano osobowość zwykłych ludzi w kontekście poglądów oraz postaw politycznych. Z czasem jednak badacze tworzący na gruncie tej dziedziny uczynili centrum swoich zainteresowań relacje międzygrupowe ${ }^{54}$. Wydaje się, iż podobny przełom potrzebny jest i politologom, co zdają się zauważać niektórzy, jak chociażby wspomniany Dominique Moïsi, podkreślający, że jednym z użytecznych modeli wyjaśniania tego, co się dzieje na świecie może być kartografia emocji, która miałaby obejmować takie elementy jak: opinia publiczna, oświadczenia przywódców politycznych, wytwory kulturowe

52 D. Rihtman-Auguštin, op. cit., s. 271.

53 A. Popławska, Podejście antropologiczne a metody historyczne i socjologiczne na terenie nauk politycznych, [w:] B. Szklarski (red.), op. cit., Warszawa 2008, s. 33.

54 D.O. Sears, L. Huddy, R. Jervis, Psychologie leżace u podstaw psychologii politycznej, [w:] Psychologia polityczna, D.O. Sears, L. Huddy, R. Jervis (red.), Kraków 2008, s. 3-7. 
(film, literatura, sztuka) oraz architektura. Warto podkreślić, że Moïsi pod pojęciem opinii publicznej rozumie to, „co ludzie myślą o sobie, o swojej teraźniejszości i przyszłości” ${ }^{35}$ i wydaje się, że przy pomocy takiego sformułowania można byłoby również próbować definiować wyobrażenia zbiorowe.

Wiemy przecież, jak łatwo politycy rozbudzają zbiorowe nadzieje, zaszczepiając wiarę w nastanie lepszego jutra i stworzenie doskonalszego świata, choć zwykle rzeczywistość koryguje takie świetlane wizje. Wprawdzie ów fenomen przybiera na sile w okresie kampanii wyborczych, ale również codzienność obfituje w przypadki opakowywania projektów obietnicami zmiany sytuacji na lepsze. Postęp wydaje się bardzo użyteczną metaforą, przy jej użyciu można tłumaczyć wiele decyzji politycznych, co automatycznie neguje argumenty przeciwników, bowiem postępowi nie wypada się sprzeciwiać.

Andrzej Sepkowski zauważa, iż to właśnie nadzieja na lepsze jutro i zbudowanie lepszego świata motywują do działania, inspirują wybuchy rewolucji ${ }^{56}$. Przy pomocy nadziei wyjaśniać można najróżniejsze wydarzenia i nie chodzi tu wyłącznie o zbrojne czyny inspirowane chęciami poprawy sytuacji. Wiele można byłoby napisać o Solidarności, wszelakich rewolucjach, Arabskiej Wiośnie, Euromajdanie, a nawet erupcjach nadziei towarzyszących Polakom podczas kolejnych zrywów powstańczych. Ale z drugiej strony nadzieja motywuje także mniej donośne działania, jak np. wszelkie inicjatywy obywatelskie, zbieranie podpisów pod wnioskiem o referendum itd.

Niemniej inspirujące dla politologicznych analiz wydaje się upokorzenie, leżące u podstaw rozlicznych wydarzeń, rzutujących na losy całego świata. Przecież wybuch Arabskiej Wiosny poprzedzały długie lata apatii i rezygnacji, które jednak w pewnym momencie wyzwoliły pokłady nadziei na możliwość poprawy sytuacji. Jean Ziegler pisze, że „niedorozwój gospodarczy skazuje swoje ofiary na życie pozbawione nadziei, ponieważ ich przeznaczenia nie da się zmienić" ${ }^{57}$. Jednak w pewnym momencie przedłużające się poniżenie motywuje do działania, czego potwierdzeń w historii odnajdujemy bardzo wiele - od powstania Spartakusa, poprzez rewolucję bolszewicką, po wspomnianą Arabską Wiosnę. W takich przypadkach upokorzenie przeradzało się w nadzieję.

Przeciwstawną emocją, wpływającą na zachowania zbiorowe, jest strach. Moïsi słusznie stwierdza, że odrobina strachu może rodzić nadzieję, inspirować i pobudzać do działania, np. projekt integracji europejskiej narodził się ze strachu przed nową wojną, ale zbyt duży strach staje się dysfunkcyjny,

55 D. Moïsi, op. cit., s. 37.

56 A. Sepkowski, op. cit., s. 83.

57 J. Ziegler, Imperium hańby, Warszawa 2011, s. 123. 
paraliżuje, zmniejsza zdolność nawiązywania relacji z bliźnimi ${ }^{58}$. Francuski badacz i analityk uznał świat Zachodu za kulturę strachu i wydaje się, że mimo upływu lat ta hipoteza pozostaje jak najbardziej uzasadniona. Nie jest tajemnicą, że człowiek boi się tego, co nieznane, a wzrastający odsetek imigrantów oznacza dla Europejczyków nową sytuację, bowiem - jak podkreślają znawcy przedmiotu - proces pełnej asymilacji polegać musi na niwelowaniu różnic w obu kierunkach ${ }^{59}$. Atmosferę strachu potęgują kolejne zamachy terrorystyczne, które obracają się przeciwko samym przybyszom, paradoksalnie nie tylko pochodzącym z szeroko rozumianego Orientu, ale również z innych części Europy. Trywializmem będzie uwaga, iż nastroje antyimigranckie wzmógł tzw. kryzys migracyjny, skutkujący m.in. niezwykle silną reprodukcją kultury strachu i atmosfery zagrożenia, które również dotarły do Polski i krajów regionu.

Nie dysponując miejscem na pogłębioną analizę problemu oraz refleksję nad pozostałymi emocjami, chcemy jedynie zauważyć, iż dla politologa próbującego tłumaczyć postawy i nastroje społeczne, a także analizować programy ugrupowań politycznych, zwrócenie się ku temu czynnikowi wydaje się niezwykle przydatne. Tym bardziej, iż, jak pokazuje praktyka, politycy lubią wykorzystywać zbiorowe emocje i odpowiednio nimi sterować w celu zapewnienia sobie poparcia. Można nawet zasugerować spostrzeżenie, iż dekonstrukcja tegoż fenomenu wydaje się nieodzowną strategią w poszukiwaniu nowych wyjaśnień coraz bardziej skomplikowanej rzeczywistości politycznej.

Celem przedstawionego tekstu miała być próba kategoryzacji pojęcia wyobrażeń zbiorowych, które - choć pojawia się w naukowym dyskursie - rzadko samo w sobie staje się przedmiotem refleksji. Autorka, traktując wyobrażenia zbiorowe jako system powiązanych ze sobą elementów (takich jak: mity i stereotypy, pamięć zbiorowa, tożsamość zbiorowa, system aksjonormatywny z kulturą, religią i tradycją, zbiorowe emocje), pokrótce opisała każdy z nich z perspektywy przydatności $\mathrm{w}$ analizowaniu i wyjaśnianiu fenomenów świata polityki. Na każdym etapie uwidaczniało się rosnące zainteresowanie politologów omawianymi pojęciami, co koresponduje z trendem zakreślania możliwie szerokich granic politologii jako nauki badającej wszystko, co ma bezpośredni związek ze sferą polityki.

Można więc się spodziewać, iż w najbliższym czasie wyobrażenia zbiorowe na stałe wypełnią refleksję politologiczną, co - jak zostało zauważone - powinno w znaczący sposób wzbogacić tę dyscyplinę. To wydaje się niezwykle ważne w czasach zwrotu ku humanistyce zintegrowanej i tendencji do wychodzenia ponad podziały, często utrudniające całościowe podejście do problemów

58 D. Moïsi, op. cit., s. 150.

59 P. Savidan, Wielokulturowość, Warszawa 2012, s. 3. 
badawczych. Coraz częściej słychać nawoływania do zastosowania możliwie najszerszego, interdyscyplinarnego spektrum metod i technik jako jedynego sposobu nabycia kompleksowej wiedzy warunkującej eksplorację zjawisk społecznych, politycznych, kulturowych. Wydaje się, iż wyobrażenia zbiorowe okażą się bardzo użytecznym podejściem przy budowaniu złożonych strategii wyjaśniających świat polityki.

\section{Bibliografia}

Assmann J., Pamięć kulturowa. Pismo, zapamiętywanie i polityczna tożsamość w cywilizacjach starożytnych, Warszawa 2008.

Breslavskaia E., Załęski P., Tradycja w polityce historycznej i symbolach politycznych niepodległego Kirgistanu, [w:] Tożsamości narodowe na obszarze postradzieckim. Między dziedzictwem a tradycja wynalezioną, P. Załęski, E. Breslavskaia, M. Włodarkiewicz (red.), Warszawa 2012, s. 75-100.

Chaszczewicz-Rydel M., Obrazy Bałkanów. Mity stereotypy, nowa imagologia, Wrocław 2013.

de Deugt N., Hoen H.W., Dovetailing Economics and Political Science, Assen 2010.

Dziekanowska M., Pamięć a tożsamość zbiorowa, [w:] Pamięć jako kategoria rzeczywistości społecznej, J. Styk, M. Dziekanowska (red.), Lublin 2012, s. $25-38$.

Fukuyama F., Polityka kobiet, [w:] Prognozy. Trzydziestu myślicieli o przyszłości, S. Griffiths (red.), Poznań 2006, s. 25-38.

Hein H., Historische Mythos- und Kulturforschung, [w:] „Mythos”, no. 2: Politische Mythen, P. Tepe (red.), Würzburg 2006, s. 30-45.

Hopfinger M., Kultura: scalanie i wybór, [w:] Perspektywy badań nad kultura, R.W. Kluszczyński, A. Zeidler-Janiszewska (red.), Łódź 2008, s. 23-30.

Jabłoński A.W., Teorie i podejścia $w$ badaniach zmiany systemów politycznych, [w:] Podejścia badawcze i metodologie w nauce o polityce, B. Krauz-Mozer, P. Ścigaj (red.), Kraków 2013, s. 73-92.

Johnson P., Prawie wszędzie widze przesłanki do optymizmu, rozm. przepr. B. Wildstein, [w:] B. Wildstein, Profile wieku, Warszawa 2000, s. 79-92.

Kapciak A., Kultura nowoczesności a niepewność znaczeń, [w:] Spotkania $z$ kulturą. Antoninie Kłoskowskiej w piąta rocznicę śmierci, J. Kurczewska, E. Tarkowska (red.), Warszawa 2006, s. 48-67.

Karnat-Napieracz A., Tożsamość, czyli świadomość Redivivus, Kraków 2009. 
Karwat M., Metawiedza, esencja, forma, pragmatyka - cztery płaszczyzny badań teorii politycznych, [w:] Podejścia badawcze i metodologie w nauce o polityce, B. Krauz-Mozer, P. Ścigaj (red.), Kraków 2013, s. 45-72.

Kołodziej J.K., Wartości polityczne - problem badawczy dla politologa, [w:] Podejścia badawcze i metodologie w nauce o polityce, B. Krauz-Mozer, P. Ścigaj (red.), Kraków 2013, s. 185-205.

Krauz-Mozer B., Ścigaj P., Sklep z podróbkami? Podejścia badawcze i metodologie w nauce o polityce, [w:] Podejścia badawcze i metodologie w nauce o polityce, B. Krauz-Mozer, P. Ścigaj (red.), Kraków 2013, s. 9-30.

Le Goff J., Historia i pamięć, Warszawa 2007.

Lorenz C., Unstuck the Time. Or: the Sudden Presence of the Past, [w:] Performing the Past: Memory, History, and Identity in Modern Europe, K. Tilmans, F. van Vree, J. Winter (red.), Amsterdam 2010, s. 67-104.

Lukes S., Durkheim. Życie i dzieło, Warszawa 2012.

Łotman J., Uspieński B., O semiotycznym mechanizmie kultury, [w:] Semiotyka kultury, wybór i oprac. E. Janus, M.R. Mayenowa, Warszawa 1977, s. 147-170.

Łyżwa P., Aksjologiczne uwarunkowania polityki jako sfery społecznej - zarys problematyki, „Wrocławskie Studia Politologiczne” 2012, nr 13, s. 23-36.

Mariański J., Świadomość moralna Polaków w procesie przemian - główne tendencje, [w:] Style życia, wartości, obyczaje. Stare tematy, nowe spojrzenia, A. Jawłowska, W. Pawlik, B. Fatyga (red.), Warszawa 2012, s. 100-122.

Marković M., Ogledi o nacionalnom i demokratkom pitanju. Postjugoslovenski slučaj Srbije, Beograd 2010.

Máte-Tóth A., Vukoja M., Uloga katoličke Crkve u konstrukcji identiteta u Multi religijskom društvu, [w:] Bosna i Hercegovina - Europsjka zemlja bez ustava. Znastveni, etički i političkii zazov, M. Džolan (red.), Sarajevo 2013, s. $58-74$.

Mihailesku V., Svako dnevnicanijeviše ono što je bila. Beleške jedno balkanskog antropologa u doba tranzicije, Beograd 2002.

Mikl-Horke G., Soziologie: Historischer Kontext und soziologische Theorie-Entwürfe, München 2011.

Moïsi M.D., Geopolityka emocji. Jak kultury strachu, upokorzenia, nadziei przeobrażają świat, Warszawa 2012.

Pietraś Z.J., Decydowanie polityczne, Warszawa 2011.

Popławska A., Podejście antropologiczne a metody historyczne i socjologiczne na terenie nauk politycznych, [w:] Mity, symbole i rytuały we współczesnej polityce, B. Szklarski (red.), Warszawa 2008, s. 29-36.

Prajzner K., Narratologia w perspektywie badań medioznawczych, [w:] Perspektywy badań nad kultura, R.W. Kluszczyński, A. Zeidler-Janiszewska (red.), Łódź 2008, s. 169-190. 
Ricœur P., Żyć aż do śmierci oraz fragmenty, Kraków 2008.

Rihtman-Auguštin D., Ulice moga grada. Antropologija domaćeg terena, Beo$\operatorname{grad} 2000$.

Ross M.H., Cultural Contestation in Ethnic Conflict, Cambridge 2007.

Roth K., Od socijalizma do Evropske unije. Ogledi o svakodnevnom životu u jugoistočnoj Evropi, Beograd 2012.

Roth K., Slike u glavama. Ogledi o narodnoj kultury u jugoistočnoj Evropi, Beo$\operatorname{grad} 2000$.

Saryusz-Wolska M., Traba R., Wprowadzenie, [w:] Modi memorandi. Leksykon kultury pamięci, M. Saryusz-Wolska, R. Traba (red.), Warszawa 2014, s. 13-30.

Savidan P., Wielokulturowość, Warszawa 2012.

Sears D.O., Huddy L., Jervis R., Psychologie leżące u podstaw psychologii politycznej, [w:] Psychologia polityczna, D.O. Sears, L. Huddy, R. Jervis (red.), Kraków 2008, s. 1-16.

Sepkowski A., Zbawić się na ziemi. O soteriologii immanentnej, Łódź 2014.

Sielski J., Pierwotne kategorie aksjologicznej analizy decyzyjnej, Katowice 1997.

Singer P., Nowa etyka, [w:] Prognozy. Trzydziestu myślicieli o przyszłości, S. Griffiths (red.), Poznań 2006, s. 266-275.

Słownik języka polskiego, http://sjp.pwn.pl/szukaj/wyobra\%C5\%BCenie.html [dostęp: 3.02.2015].

Smith A.D., Etniczne źródła narodów, Kraków 2009.

Spohn W., National Identities and Collective Memory in an Enlarged Europe, [w:] Collective Memory in the Enlarging Europe: The Effects of Integration and Enlargement, K. Eder, W. Spohn (red.), Abington 2005, s. 1-14.

Szklarski B., W poszukiwaniu wspótczesnych powinowactw antropologii i polityki, [w:] Mity, symbole i rytuały we współczesnej polityce, B. Szklarski (red.), Warszawa 2008, s. 7-12.

Szpociński A., Wizualizacja pamięci społecznej, [w:] Pamięć zbiorowa jako czynnik integracji i źródło konfliktów, A. Szpociński (red.), Warszawa 2009, s. 227-237.

Ślawska M., Proza autobiograficzna pokolenia jugonostalgików, Wrocław 2013. Śnieżyński K., Pamięć religijna jako akt lojalności względem świata, [w:] Pamięć - kultura - edukacja, A.B. Bieś, M. Chrost, B. Topij-Stempińska (red.), Kraków 2011, s. 11-26.

Tappenbeck I., Phantasie und Gesellschaft: zur soziologischen Relevanz der Einbildungskraft, Würzburg 1999.

Trompenaars F., Hampden-Turner Ch., Siedem wymiarów kultury. Znaczenie różnic kulturowych w działalności gospodarczej, Kraków 2002. 
Wolff-Powęska A., Pamięć - brzemię i uwolnienie. Niemcy wobec nazistowskiej przeszłości (1945-2010), Poznań 2011.

Zaprogramowanie kulturowe - SOFTWARE naszego umystu, [w:] Zaprogramowanie kulturowe narodów Europy, A. de Lazari, O. Nadskakuła, M. Żakowska (red.), Łódź 2007, s. 5-15.

Ziegler J., Imperium hańby, Warszawa 2011.

Żarnowski J., Metamorfozy społeczne 3. Historia społeczna. Metodologia - ewolucja-perspektywy, Warszawa 2011.

\begin{abstract}
The aim of the text is to define and examine the concept of collective representations which was introduced by Émile Durkheim many years ago, but since that not many scholars have brightly analysed it. According to the author, collective representations can be described as the system of following elements: myths and stereotypes, collective memory, collective identity, axio-normative system (including culture and religion) and collective emotions. All the elements mentioned above are related to each other, so one can say that the system constantly works. That is why collective representations are not constant, they regularly evolve according to political atmosphere and ideological context.
\end{abstract}

Keywords: collective representations, collective memory, myths, stereotypes, collective identity 